\title{
Notes on the Western Race of the Pigeon Hawk
}

by Glen A. Fox, Saskatchewan Falconry Association, Regina

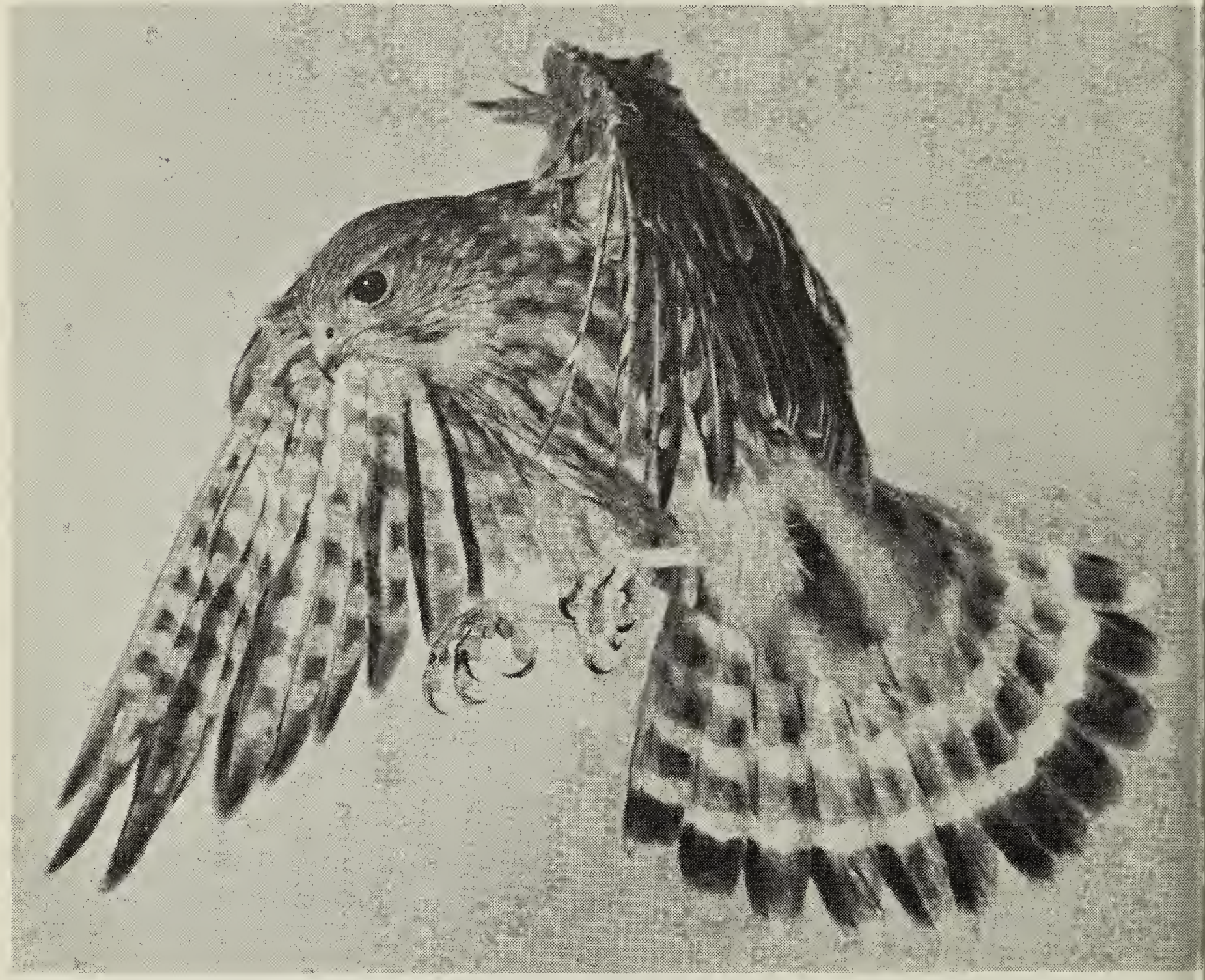

Immature female Falco columbarius richardsonii

Photo by C. G. Hampson

Although it is widely distributed in North America, the Pigeon Hawk or Merlin (Falco columbarius) has not been studied extensively. The eastern subspecies $F$. c. columbarius has been the subject of brief papers by Craighead and Craighead (1940) and Lawrence (1949). However, Bent (1938) gives the only account of the life history of the plains or western subspecies $F$. c. richardsonii. Friedmann (1950) gives an account of the distribution of this subspecies and brief notes are scattered throughout the literature.

I studied this subspecies on its breeding grounds during 1958, 1959, and 1960 at 15 active nests in the general vicinity of Kindersley, Saskatchewan.
To supplement this information used further nesting records from the files of the Prairie Nest Records Scheme. Information concerning sex age, and stomach contents of speci mens as well as descriptions of clutch size and nests from which they came was supplied by personnel of museums in both Canada and the United States. Letters of inquiry were sent to all falconers and ornithologist known to be familiar with this sub species. A request for information ap peared in the Wilson Bulletin on my behalf. The bulk of the material on non-breeding birds and captives con tained herein was obtained from these sources. 


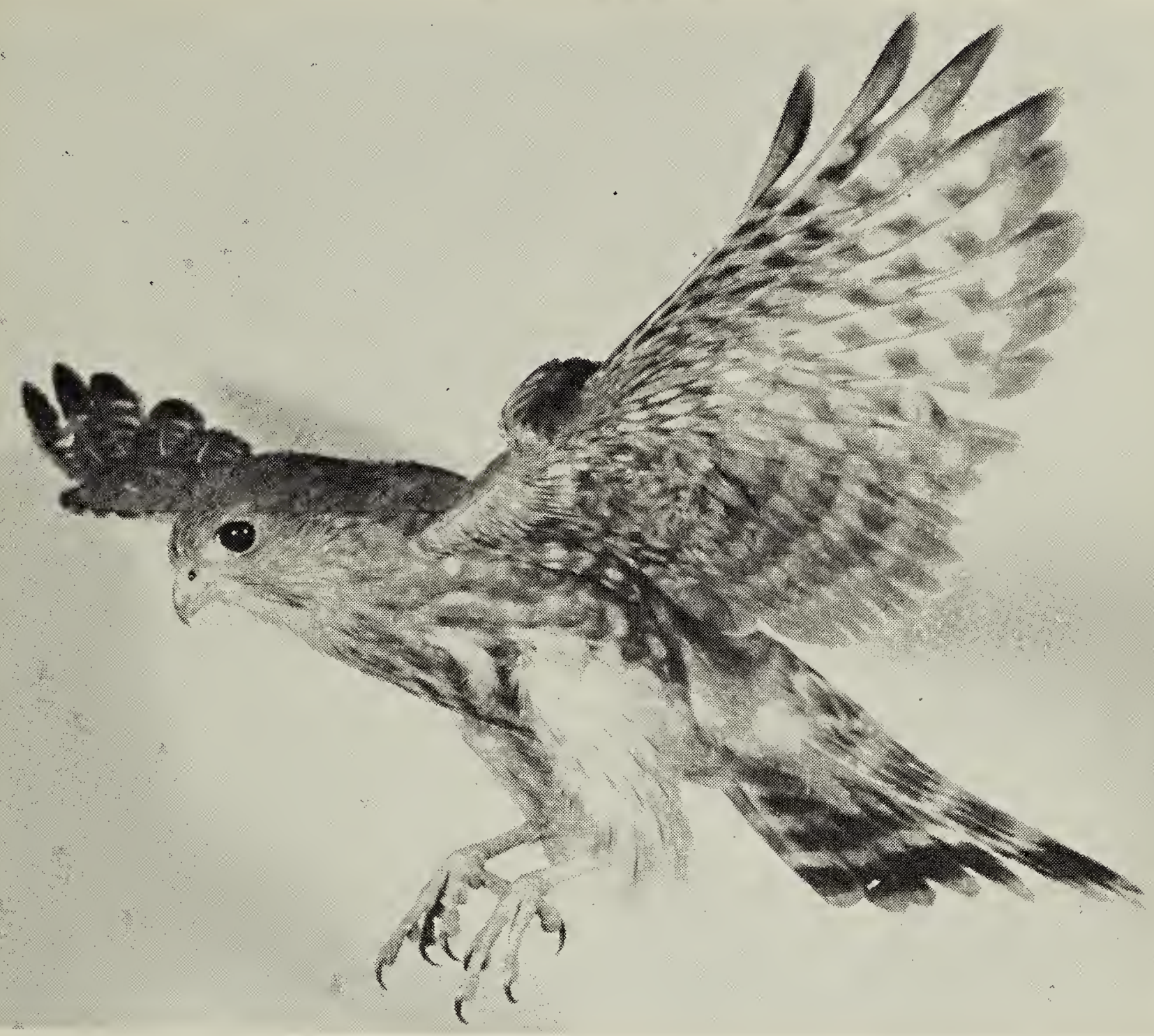

Photo by C. G. Hampson

Immature female Falco columbarius richardsonii

\section{DISTRIBUTION}

According to the A.O.U. Check-list (1957) F. c. richardsonii "breeds in the prairie and grove belt of southern Alberta (Lac la Nonne, Red Deer River, Calgary), southern Saskatchewan (Carleton, Pelly), and southwestern Manitoba (Oak Lake) south to northern Montana and northern North Dakota. Winters from Wyoming (Green River, La Bonte Creek, Bridger Mountains) and Colorado (Walkers Basin; El Paso, Boulder, and Larimer counties) to California (uncommon), Sonora, Zacatecas, and Tamaulipas. Migrates through South Dakota, central and western Nebraska, and Kansas; casual in British Columbia (Okanagan Landing), Missouri (Stone County), Illinois (Warsaw), Iowa, and Oklahoma."

Examination of recent literature, museum specimens from institutions mentioned elsewhere, and sight records by competent observers gener- ally supports the distribution outlined above.

Enderson (pers. corr. 1961) describes a nest found in Albany County, Wyoming, which he believed to be of this subspecies but no specimens were taken. The Wyoming Game and Fish Commission (pers. corr. 1961) report that a member of their staff, $\mathrm{Mr}$. Robert L. Patterson, located a nest of this subspecies in Weston County, Wyoming, in the 1950's but no specimens were taken. These sight records may represent an extension of the breeding range.

Breeding records for Saskatchewan include the following locations: Kindersley, Battleford, Cypress Hills, Beechy, Harptree, Eastend, Craven, Nokomis, Nipawin, Prince Albert, Wolseley, Yorkton, Moose Jaw, Crescent Lake, and Fort Qu'Appelle. These records are from the author's own observations, the files of the Prairie Nest Records Scheme, and from Museum specimerss. 


\section{BREEDING BIOLOGY}

\section{Nesting Habits.}

Pigeon Hawks show a tendency to breed in mixed woods, along river banks and islands, and in natural prairie areas. Some preference is shown for shelterbelts of deserted farms, especially where the trees are spaced well apart and bare of branches for eight to ten feet from the ground. About half of the nests seen on the prairies were within one-half mile from water. Deciduous trees of the following types were used: aspen poplar (Populus), box elder (Acer), willow (Salix), and birch (Betula). The coniferous trees used were the white spruce (Picea glauca), and jack pine (Pinus banksiana). Nests were from 8 to 35 feet above the ground. Almost all nests were situated in the upper half of the tree and as close to the trunk as possible. Vacant nests of the Black-billed Magpie and the Common Crow or natural cavities are habitually occupied. For a summary of this data see Table 1.

Table 1. Nesting habits of the western race of the Pigeon Hawk*

\section{Habitat:}

Open prairie, vacant farm shelterbelts

Mixed woods, bluffs, river edges and islands

Coniferous forest

\begin{tabular}{cc}
$\begin{array}{c}\text { Number of } \\
\text { Nests }\end{array}$ & $\begin{array}{c}\text { Per } \\
\text { Cent }\end{array}$ \\
7 & 28 \\
12 & 48 \\
6 & 24 \\
\hline 25 & 100
\end{tabular}

Nest Site:

Deciduous tree

Coniferous tree

$\begin{array}{rr}21 & 84 \\ 4 & 16 \\ 25 & 100\end{array}$

Height of Nest:

5 to 14 feet
15 to 24 feet

25 to 35 feet

\begin{tabular}{rr}
10 & 40 \\
13 & 52 \\
2 & 8 \\
\hline 25 & 100
\end{tabular}

Type of Nest:

Former nest of Common Crow

Former nest of Black-billed Magpie

Natural cavity in tree

\begin{tabular}{rr}
13 & 52 \\
10 & 40 \\
2 & 8 \\
\hline 25 & 100
\end{tabular}

*Data from author's observations, files of Prairie Nest Records Scheme, and Museum specimens.

\section{Arrival on Breeding Areas and Behaviour:}

The male Pigeon Hawks arrive on the breeding territory in late February or early March. The females arrive about a month later. Each member of the pair has a favorite perch, often a branch of a tall dead tree, which overlooks the territory. Observations of eight nests show that the territory is defended against human intruders from the date of the male's arrival, with peak intensity when the young are about two weeks old, then decreasing rapidly in intensity until such defence disappears about a month after the young are fledged. Both sexes participate in defence, the female being the more aggressive in most cases. Frequently the human intruder is met by a screaming male while still one-half mile distant from the nest. Actual striking of human intruders has been observed. The same areas are frequently occupied in successive years, although the same nest is not always used, especially if young were fledged in the previous year.

\section{Relationship with Other Species:}

Table 2 summarizes observations of interspecific relations. Male Pigeon 
Hawks have been observed driving crows from their territory by stooping close, and on one occasion, by striking the intruder. Crows, magpies, Swainson's Hawks, and Ferruginous Hawks nest within Pigeon Hawk territories but no encounters have been observed.

In mid July, 1959, a party of one Robin, a pair of Baltimore Orioles, one Common Grackle, and several House Sparrows mobbed my captive male in an outdoor pen. At this time these usually timid birds permitted my close approach, constantly watching the Pigeon Hawk and protesting loudly. After some time they ventured closer, the grackle trying to gain entrance to the pen. When I dispersed them they returned almost immediately, the grackle arriving first.

Beebe, in describing (pers. corr. 1961) the encounters of his tame female, listed in Table 2, emphasizes its intolerance of accipiters. Antagonism between the Pigeon Hawk and any larger falcon seemed to be intensified if the larger bird took quarry.

Egg-Laying, Incubation and Brood Size:

Egg-laying commences on the Canadian prairies during the first two weeks of May or approximately six weeks after the male first establishes the territory. The duration of egg laying in the aeries under observation was from May 4 to June 5 , with the peak on May 20. Detailed observations of two nests, and records for the duration of the laying period in three others, show that the average interval between eggs is 48 hours.

\section{Table 2. Interspecific antagonism}

\section{Chased by Pigeon Hawks: Observer}

Common Crow - Sealy

Clark's Nutcracker ........... Enderson

Peregrine Falcon -.-- Hampson, Beebe

Prairie Falcon - Hampson

Great Horned Owl _.......... Hampson

Sparrow Hawk* -___ Beebe

Sharp-shinned Hawk* _........ Beebe

Cooper's Hawk*

Pigeon Hawks chased by:

Red-winged Blackbird

Eastern Kingbird

Red-eyed Vireo

Fox

Yellow Warbler

Hampson

Hampson

Robin Street

Sparrow Hawk* _._-_._- Beebe

Peregrine Falcon* ${ }^{*}$

*Encounters involving tame female Pigeon Hawk.
The mean clutch in a sample of 27 nests was 4.48 eggs, the mode was four, range three to seven. Partial incubation begins before the clutch is complete and full-time incubation begins with the last egg of the clutch. There is some evidence that the male shares incubation duties. Incubation lasts from 29 to 31 days. Only the female has been noted brooding; brooding lasts until the young are about two weeks old. Fledging takes from four to five weeks. The average number of downy young was 2.7 per nest, 2.6 of which were fledged.

\section{Nesting Success:}

Fragmentary data is available from some 30 nests; however, complete records concerning nesting success are available for only 10 of these. This data was recorded from repeated visits to eight nests in the Kindersley area and two nests in the Battleford area visited by Sealy and is summarized in Table 3.

Of 45 eggs laid, 27 or $60 \%$ hatched. Of the 27 that hatched, 26 or $96 \%$ were fledged. Thus the total nesting success was $58 \%$.

\section{Development of Young:}

At hatching the young are covered with a sparse white down, except for the protruding abdominal region. The cere and feet are yellow, the eyelids and hooded beak are bluish. The white egg tooth is visible. They are weak and immobile, show only a feeble grasping reflex when moved: The eyes are closed.

At three days of age the eyes are open. At five days the young have been observed to stretch their flipperlike wings above their heads, and back to the edge of the nest to defecate.

At 10 days active yawning and wing-flapping occur. The primary and secondary sheaths are visible.

At 15 days the facial area and much of the remaining body area show feather sheaths or developing feathers. When disturbed the young scream, and active use of the feet when feeding is noted.

At 20 days feathers are evident on all regions. The wings are almost fully developed and the down is almost absent on the breast. Much time is spent in preening. The females may be separated from the males, in most cases, by their larger feet and tarsi and bulkier form. 
At 25 days of age the young are fully feathered, but some down is still present. They beg food from their parents, "play" with nest mates, and sleep in adult position.

At 30-35 days of age they leave the nest for the surrounding branches. They can fly from 50-150 yards when disturbed but are not strong enough to return to the trees and the flights are little more than extended glides to the ground. They are dependent, to some extent, on their parents for food for more than a month after they leave the nest.

\section{Mortality of Pigeon Hawks after Fledging:}

If one examines a sample of museum specimens, the ratio of subadults to adults decreases from $60 \%$ in August to $30-40 \%$ in January when molt begins. Over $70 \%$ of total returns on

\section{Table 3. Reproductive success of} Pigeon Hawk

Number of Nests 10

Eggs laid 45

Downy young 27

Fledged young 26

Average number of eggs per nest

Average number of downy young per nest

Average number of fledged young per pair

Pigeon Hawks banded as nestlings occur within the first year. Nestlings banded in Saskatchewan and Alberta have been recovered within their first year in New Mexico, Kansas, and Arizona, and the Canadian prairies.

\section{Sex Ratio:}

Observations of 30 nestlings indicate slight excess $(52 \%)$ of male Pigeon Hawks. Nestlings were sexed on the basis of larger feet and bulkier form of the female, and more rapid development of the males. However, in a random sample of 151 museum specimens $48 \%$ were males.

\section{Bathing and Reactions to Water:}

No wild Pigeon Hawks have been observed bathing. However they show a preference for breeding areas with permanent water present, and moreover, seem to find such areas attractive at any time of the year. Captive Pigeon Hawks show the same fondness for bathing that is so character- istic of the larger members of the genus.

\section{Flight:}

The flight of the Pigeon Hawk is similar to that of other falcons, being swift and direct, with deep, regular wingbeats. Even in normal flight they attain speeds of upwards of 45 miles per hour. Enderson (pers. corr. 1961) followed a wintering female carrying a Horned Lark at this speed for half a mile. In pursuit of quarry the Pigeon Hawk has an ability to twist and turn which probably exceeds that of any other falcon and resembles the similar ability of the accipiters. Like other falcons, the Pigeon Hawk attains its greatest speed when stooping, at which times estimates of 60 to 90 miles per hour would seem to be in order. Pigeon Hawks soar infrequently, but have a curious hovering flight, with wings extended and tail spread, flapping the distal portions of the wing like a kingbird. This flight is characteristic of fledglings and is observed most noticeably in adult Pigeon Hawks when they are circling the intruder at the nest site, and is observed occasionally in hunting Pigeon Hawks.

\section{MIGRATION}

The juvenile Pigeon Hawks drift southward in mid-August. The fall movement of migrant Pigeon Hawks on the Saskatchewan prairies seems to to be over by mid-October. Flavin (pers. corr. 1961) observes that the Pigeon Hawk arrives in the Denver area during the last two weeks of October. McCreary (1937) gives the date of autumn migration in Wyoming as being from September 2 through November 27. In spring, according to McCreary, the dates of the greatest movement in Albany County, Wyoming are from March 13 through May 24. Flavin indicates that they have moved out of the Denver area by mid-March.

Specimen records suggest that fewer immatures winter on the prairies than adults. Also, banding recoveries indicate that juvenile Pigeon Hawks tend to migrate farther south than adults. Nestlings banded on the Canadian prairies have been recovered in Kansas, Arizona, and New Mexico.

\section{WINTERING}

The largest wintering populations of the western race of the Pigeon Hawk 


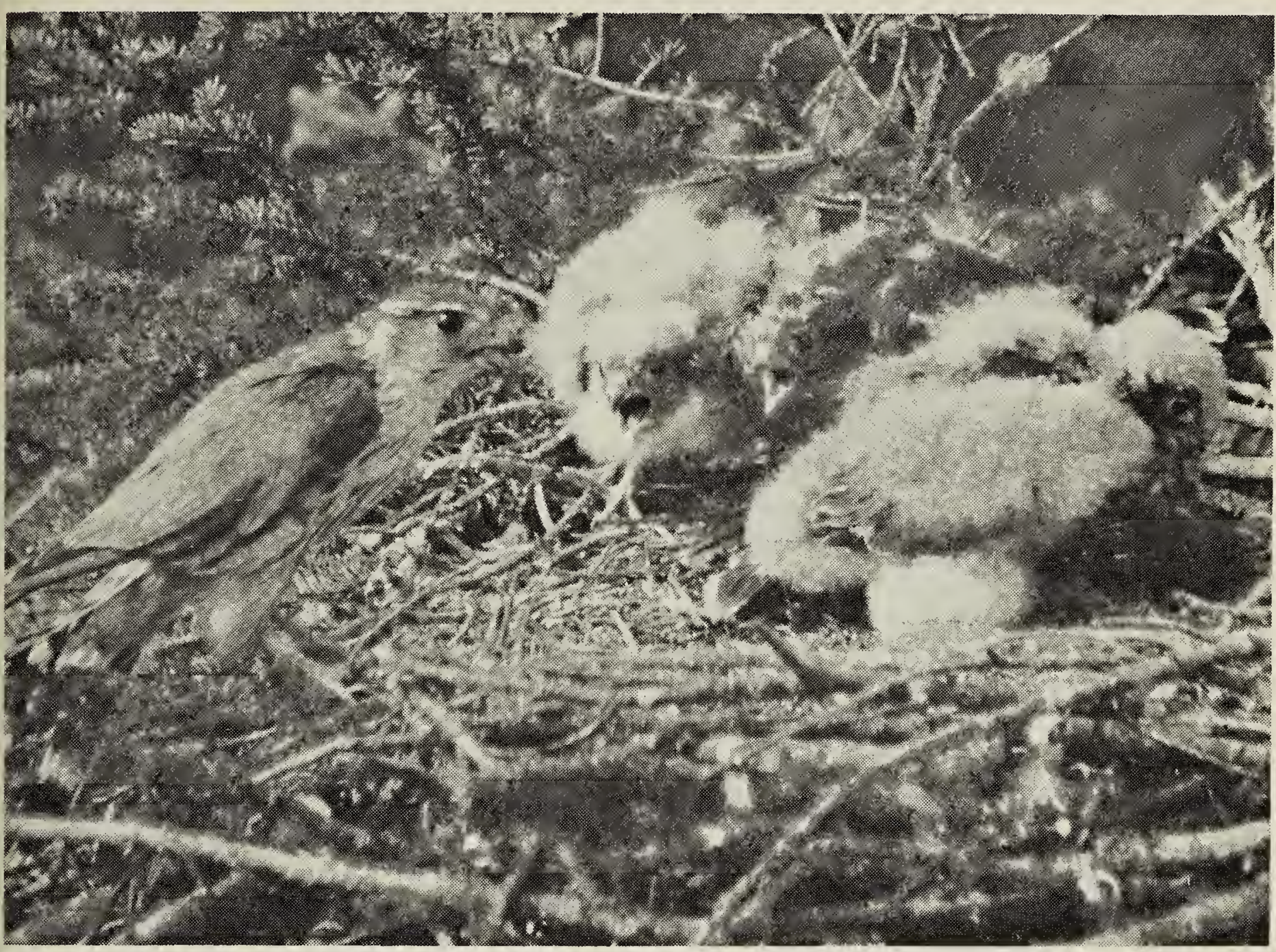

Pigeon Hawk with nest and young.

Photo by R. R. Taylor

seem to be in Wyoming and Colorado. Enderson (pers. corr. 1961) reports that the preferred habitat in Wyoming is winter wheat stubble. According to Flavin (pers. corr. 1961), in Colorado the Pigeon Hawk is found chiefly on the plains in very open country, and along or near creek beds, where there are stands of cottonwoods and willows. He says there is a marked preference for fence posts and lower perches even when telephone poles are available.

Wintering birds seem to wander at random. However, in certain cases a single bird may stay for some time in a favorable location, for example at grain elevators or farm buildings, probably because of the abundance of small birds attracted by the spilled grain.

\section{FOOD HABITS}

Species of suitable size for quarry that are found inhabiting the same areas on the prairies as breeding Pigeon Hawks include Killdeer, Spot- ted Sandpiper, Eastern Kingbird, Horned Lark, Barn Swallow, Brown Thrasher, Robin, Loggerhead Shrike, Starling, House Sparrow, Western Meadowlark, Brewer's Blackbird, Red-winged Blackbird, Common Grackle, Brown-headed Cowbird, Vesper Sparrow, Song Sparrow, Savannah Sparrow, Baird's Sparrow, and Chestnut-collared Longspur. These species are also found in the parkland areas of the Pigeon Hawk's nesting range along with many other woodland birds such as woodpeckers.

Table 4 summarizes the information available on food at the nest. With one exception, the Baird's Sparrow, all species regularly taken are abundant in the areas frequented by breeding Pigeon Hawks. Horned Larks and the Fringillidae all inhabit open areas, nesting on the outer fringes of cover or on the open prairie. The inexperienced young are very easy prey to the Pigeon Hawks, as are incubating adults. With the exception of kingbirds, shrikes, flickers and other woodpeckers, all species feed on the 
ground, some with gregarious habits, where they are vulnerable to the swift attacks of Pigeon Hawks. Blackbirds, starlings, meadowlarks, shrikes, and kingbirds all perch in open places where they are conspicuous and can be struck from behind with no warning. If in the open, the slow undulating flight of the flicker and other woodpeckers would also make them vulnerable to attack.

The species listed in Table 5 as prey taken by non-breeding birds seem common in areas where taken and have in common habits which make them vulnerable to attack.
Table 4. Food at the nest

\begin{tabular}{llc}
\hline \multicolumn{1}{c}{ Species } & Observer & Per Cent \\
Horned Lark & Fox* & 53.5 \\
Brown-headed Cowbird & Fox & 13.3 \\
Vesper Sparrow & Fox & 6.7 \\
Song Sparrow - & Fox & 6.7 \\
Baird's Sparrow -.----- & Fox & 6.7 \\
Chestnut-collared & \multicolumn{2}{c}{ Fox } \\
$\quad$ Longspur & 13.6 \\
Starling - & Hampson* * \\
Red-winged Blackbird & Hampson \\
Fringillid Sparrows --- & Hampson \\
Insects: Dragon-flies & Street (1960) \\
\hline
\end{tabular}

* From a sample of 16 tarsi removed from one nest at Kindersley, Saskatchewan, and identified by Donald $H$. Baldwin of the Royal Ontario Museum.

* Remains noted in nests.

Table 5. Food taken by non-breeding birds

\section{Species}

Source of Data

Spotted Sandpiper Fox

Yellow-shafted Flicker Flavin

Horned Lark

Starling

Western Meadowlark

Red-winged Blackbird

House Sparrow

Dickcissel

\begin{tabular}{c} 
Fox, Enderson, Flavin \\
- Elavin \\
\hline-- Flavin
\end{tabular}

House Finch

Goldfinch

Savannah Sparrow

Fox, Enderson, Flavin
- Elavin
- Enderson, Flavin

Tree Sparrow

Fox, Enderson, Flavin
- Elavin
- Enderson, Flavin

Lincoln's Sparrow

Snow Bunting

Fox, Hampson, Street

$H$. G. Deignan (SI)

Unidentified Fringillid Sparrows

Insects:

Beetles

Flavin

Grasshoppers and Crickets

Caterpillars

Fisher (1863)

E. L. Weber (CNHM)

L. L. Snyder (ROM)

Fisher (1863)

C. V. Davis (MSC), Houston (1959) E. L. Weber (CNHM), Enderson, Fisher (1863)

Apparently plucking is done immediately at the site of the kill or at the nearest convenient perch. Hampson (pers. corr. 1961) notes that the prey is almost invariably brought to the nest after plucking and is often decapitated. Skeletal remains found in nests consisted of tarsi, humeri, and sternae, but never skulls.

Webster (letter) reports that in Colorado, wintering Pigeon Hawks fly close to the ground in the manner of the Prairie Falcon, flying at high speeds into flocks of Horned Larks. He reports that on this type of attack they seldom make a second attempt at any individual in the flock should they miss.

\section{Predatory Behaviour of Captive Birds:}

Frank Beebe (pers. corr. 1961) care- fully described the habits of his trained female as follows:

"During its first season this merlin was flown with some success as a hunting falcon, flying directly from the fist. Flights were had on the following species: meadowlark, European skylark, house sparrow, Brewer's blackbird, robin, goldfinch, killdeer, mourning dove, California quail, and band-tailed pigeons. The highest number of flights were on house sparrows, meadowlark, goldfinch and killdeer. Successes were obtained on goldfinch, meadowlark, robin, house sparrow and only one killdeer, it not yet fully grown. Successful flights were invariably started by the merlin seeing the quarry walking on the ground. Intention of attack was indicated by headbobbing, the attack was absolutely 
direct with no attempt at concealment, which almost always resulted in the quarry flushing when the merlin was some considerable distance away, and most catches were aerial strikes. The first strike on such ar attack was made from directly behind in the manner of an accipiter, but subsequent tries were made as a series of short twisting stoops from above, the falcon shooting up after each attack, climbing for a few wingbeats, then twisting into another stoop. Flights were terminated by the quarry being hit and knocked down, snatched in the air, or forced out of the air and taken on the ground; or by the quarry dodging several attacks and climbing above the merlin (skylark and killdeer) or by diving into cover (meadowlark and house sparrow). Some birds regularly flew straight away and outdistanced the merlin. Mourning dove and band-tailed pigeon did this, so also, with amazing regularity, did robins. Highest successes were scored on meadowlark and goldfinch. Meadowlark were often cut out of the air in the classic method by the first strike. Goldfinches, feeding on thistle or in fields often remained oblivious to the approaching merlin until it was very close and travelling very fast; sometimes they failed to flush at all and were snatched from their perch. Goldfinches were always carried to a tree and eaten there.

"During the second season, when it was at full liberty much of the time, many flights were observed. Quarries were much the same, the bird showing a marked preference for house sparrows and goldfinch over other quarries. Except that the attack was launched from tree-top height, with consequent higher advantage and speed, there was no difference. The merlin seemed to interpret opportunity in terms of the distance a prospective quarry was from the cover, and would bide its time, especially with house sparrows, waiting for them to get well in the clear before launching an attack. It almost wiped out a little flock of fifty-odd house sparrows during the three months of June, July, and August, despite an infestation with parasites in June."

Other falconers report Pigeon Hawks taking Mourning Dove, Horned Lark, flicker, and Starlings. An adult female took as its first quarry a Gray Partridge, according to Morlan W.
Nelson (pers. corr. 1961). However, she could not hold it long enough to kill it.

\section{ACKNOWLEDGMENTS}

Responses to letters of enquiry which were used in this paper were received from Frank L. Beebe, Dr. James H. Enderson, John W. Flavin, Jr., Harold M. Webster, Morlan W. Nelson, Richard W. Fyfe, Cyril Hampson, Spencer G. Sealy, and Maurice G. Street. Their contributions are greatly appreciated.

The Saskatchewan Museum of Natural History made available the files of the Prairie Nest Records Scheme of the Saskatchewan Natural History Society: Donald H. Baldwin of the Royal Ontario Museum identified portions of several prey species. Allen J. Duvall of the U.S. Fish and Wildlife Service made available the banding records in his keeping.

Information concerning specimens was supplied by personnel of the Saskatchewan Museum of Natural History, the Royal Ontario Museum (ROM), the National Museum of Canada (NMC), the Smithsonian Institution (SI), the University of Michigan Museum of Zoology, the University of California Museum of Vertebrate Zoology, the University of Kansas, the University of Wyoming, Montana State College (MSC), North Dakota State University, the University of Oklahoma, the Denver Museum of Natural History, and the Chicago Natural History Museum (CNHM).

Finally, I wish to thank Dr. James H. Enderson, Frank L. Beebe, and Dr. Robert W. Nero for their constant encouragement, constructive criticism, and editorial assistance throughout this study.

\section{LITERATURE CITED}

American Ornithologists' Union. 1957. Checklist of North American birds. Fifth edition published by the Union, Baltimore, Md.

Bent, A. C. 1938. Life histories of North American birds of prey (part 2). U.S. National Museum Bull. 170.

Craighead, F., and J. Craighead. 1940. Nesting Pigeon Hawks. Wilson Bull., 52:241-248.

Fisher, A. K. 1863. The hawks and owls of the United States. Washington, D.C.

Friedmann, H. 1950. Birds of North and Middle America. U.S. Nat. Mus. Bull. 50, pt. 11.

Houston, C. S., and M. G. Street. 1959: The birds of the Saskatchewan River. Special pub. 2, Sask. Nat. Hist. Soc., Regina, Saskatchewan.

Lawrence, L. de K. 1949. Notes on nesting Pigeon Hawks at Pimisi Bay, Ontario. Wilson Bull., 61:75-25.

McCreary, 0. 1937. Wyoming bird life. Burgess Pub. Co., Minneapolis.

Street, M. G. 1960. Pigeon Hawk catches dragon-flies. Blue Jay, 18:24. 